\title{
Commuter Pit Stops
}

Scott Silverman, Chasen Erlanger, and Diane LeGree

Commuter students, or more accurately, students who live off campus, occupy a special place within the university. This is because we can be fairly certain of a number of the factors that detract off-campus students from campus participation: part-time or full-time jobs, family obligations, and the general logistical barriers of commuting (Silverman, Aliabadi, \& Stiles, in press). Off-campus students are frequently overlooked because staff tend to default to programming for residential students. When we intentionally target off-campus students for our programs or services, we expect them to come to us, while forgetting that the amount of time available that an off-campus student will dedicate to anything other than academic obligations is infinitesimally small compared to the amount of time we spend waiting for them to come to us (Silverman, Erlanger, \& LeGree, 2006).

Such was the case before this year when the Office of Student Life at the University of California, Riverside (UCR) piloted a Commuter Pit Stops program in the Commons (student union). Over the course of the year, only a handful of students participated, despite the free food and drinks that we all typically count on as an incentive for student participation. UCR also had the "Commuters At Riverside" (CAR) student organization to link the vast commuter student population (over 13,000 out of 17,500 students) with the university, but the participation from students we did not employ or interact with regularly was meager at best. We needed a new approach to our outreach to off-campus students who were disengaged.

Beginning in fall 2006, we redeveloped our Commuter Pit Stops and took our programs, services, and resources to our students, namely to the "premiere" student parking lot. This lot, although not considered a great location by any stretch of the imagination, is the only parking lot for student use on one half of the campus, and is easily five times as large as any other student lot. Students have affectionately named this lot "Disneyland" for its vast expanse of parking spaces, neatly divided into four numbered sections. Another convenient feature of this parking lot is that there is only one pedestrian path from that parking lot to campus. We set up our new and improved Commuter Pit Stop right where the crosswalk meets a very wide walkway.

Armed with dozens of donuts and more coffee than can be reasonably consumed during the course of even the most stressful of days, two staff members set up the Pit Stop at 6:45 a.m., and stayed until 10 or 10:30 a.m., to catch the largest influx of traffic. The Commuter Pit Stops were held on the first Wednesday and Thursday of every month. On the table, we had a variety of brochures and handouts, including many from the Department of Transportation and Parking Services. The program took the tone of a friendly "meet and greet" information portal. The specific information was tailored to both the traditional and nontraditional commuter students with a common theme

Scott Silverman (scotts@ucr.edu) is the Coordinator of First-Year Programs, Chasen Erlanger is a graduate intern, and Diane LeGree is the Director of Campus Activities and First-Year Programs, all at the University of California, Riverside. 
emphasizing university involvement.

Additionally, we were able to connect students to other resources, including text message traffic updates they could request from www.traffic.com, and construction update e-mails related to the freeways and streets surrounding campus. The Associated Students of UCR, which on their own have taken a greater interest in services and programs for commuter students, have become a valuable asset, often joining us for the Pit Stops to meet and greet students.

During the first Commuter Pit Stop this year, we quickly noticed that we were getting large surges of pedestrian traffic every few minutes, and that in between the surges, there would be a large number of students waiting for the crosswalk light to turn green.

Frequently our team would split up to reach more students. One staff member would talk with the students who stopped at the Pit Stop information portal. The other staff member would walk across the crosswalk to tell students about the Commuter Pit Stop and encourage them to stop by on their way to class. This way, even if we were not able to talk to each student one-on-one, each of them would be part of a captive audience while waiting for the crosswalk signal to turn green, which was perfect for interacting with students and disseminating information.

The major difference between our successful Commuter Pit Stops and their previous incarnation was active engagement. Actively engaging the students on their terms, in their routine, and "getting in their way" proved very effective. Students were unable to avoid hearing our offer of free coffee and donuts, and many were unable to resist. We were able to find out, from talking to students, that many had not incorporated "commuter" as part of their student identities. Quite often, students were surprised to find that our program existed. Many either assumed the university did not care about off-campus students, or that they did not really count as a commuter student because they only lived two miles away. Finding out that the university had allocated considerable resources toward serving them elevated the importance of their identity as off-campus or commuter students.

Each month's Commuter Pit Stop had its own theme or gimmick so that we would not be doing the same thing for the same people each time. We handed out Commuter Survival Guides at our first Pit Stops, and bluebooks, Scantrons, and pencils at the second. Future Pit Stops will provide tips for the commute and the schedule of remaining Pit Stops given out in mock-ups of the official University Parking citation tickets; a Commuter "Drive-Thru" where we will drive around campus in our electric cart and stop at various locations to talk to the students gathered there; and a special Homecoming theme with our mascot (the Highlander), bagpipes, and face paint.

If your campus has a sizeable commuter student population - and I think we would all say that all commuter students are significant—-then consider actively engaging students on their terms. Set up a Commuter Pit Stop near the pedestrian walkways directly leading from the most heavily trafficked commuter student parking lots. Use gimmicks and innovative activities or handouts that will appeal to your students. Not only will you have the opportunity to interact with a large number of students who would otherwise avoid interaction with you, but you will let them know that your university is 
concerned for their well-being as well as for their academic and lifelong success.

\section{References}

Silverman, S. C., Aliabadi, S., \& Stiles, M. W. (in press). Meeting the needs of commuter, part-time, transfer, and returning students. In S. Harper \& D. Tuitt (Eds.), Engaging diverse student populations: Practical approaches to enhance learning, development and outcomes among today's undergraduates. San Francisco: Jossey-Bass.

Silverman, S. C., Erlanger, C. M., \& LeGree, D. J. (2006, Winter). Commuter survival skills workshops. The Orientation Review, 35(4), 17-18. 